\title{
Mare Nostrum: Italy and the Mediterranean of Ancient Rome in the Twentieth and Twenty-First Centuries
}

\author{
Samuel Agbamu \\ King's College London \\ samuel.agbamu@gmail.com
}

\begin{abstract}
The Mediterranean has occupied a prominent role in the political imaginary of Italian Fascisms, past and present. In the 1920s to the early 1940s, Fascist Italy's imperial project used the concept of mare nostrum - our sea - taken from the vocabulary of Roman antiquity, to anchor modern Italian imperialism within the authority of the classical past. In the postwar years, following decolonization in Africa, mare nostrum receded from popular discourse, previous claims to the Mediterranean suppressed. However, in the context of the so-called refugee crisis, Italy resurrected mare nostrum, in the naming of its military-humanitarian operation, a move rejected by the contemporary Italian far right. This article argues that configurations of the Mediterranean of ancient Rome have served to yoke Africa to Italy when articulated into a Fascist, imperial ideology, as well as to reify the boundaries between Europe and the non-European other, in the xenophobic discourse of the contemporary Italian far right.
\end{abstract}

\section{Keywords}

Fascism - Italy - Libya - imperialism - romanità - migration - Mediterranean - mare nostrum

The Mediterranean is by far the deadliest region for migration in the world, and the central Mediterranean, the area between Libya and Italy, has seen the highest number of migrant casualties when compared with other parts of the 
Mediterranean. ${ }^{1}$ In June 2018, news media reported that the refugee rescue ship, the Aquarius, which patrolled the waters of the Mediterranean between Libya and Italy, had rescued about six hundred refugees from the sea. However, the far-right interior minister of Italy's then newly installed government, Matteo Salvini, forbade the boat from docking at any Italian port. The mayor of Palermo, Leoluca Orlando, symbolically defied the Rome government's injunction by offering his city as a port of refuge, explaining that 'Palermo in ancient Greek meant "complete port". We have always welcomed rescue boats and vessels who saved lives at sea. We will not stop now'.2 Orlando, by referring to the ancient Greek history of his city, was following a well-established precedent in framing the ongoing humanitarian emergency with reference to Classical, in this instance Greek, antiquity. The evocation of this pre-Roman, Greek history of a region of Italy offers a counter-narrative to discourses of Italian national unification anchored in Roman antiquity, suggesting plurality and diversity of origins in contrast to Roman antiquity which had been co-opted into totalising ideologies of nation and empire. ${ }^{3}$

In this article, I will investigate some of the ways in which the Mediterranean of ancient Rome has been configured within Italian popular political discourses in the nineteenth, twentieth and twenty-first centuries. ${ }^{4}$ I focus in

1 'Missing Migrants: Tracking Deaths along Migratory Routes,' accessed September 6, 2019, www.missingmigrants.iom.int; Maurizio Albahari, Crimes of Peace: Mediterranean Migrations at the World's Deadliest Border (Philadelphia: University of Pennsylvania Press, 2015).

2 Oliver Wheaton, 'Rescue boat carrying 600 refugees stranded in Mediterranean because no European country would let it dock', The Independent, June 11, 2018, accessed September 6, 2019, https://www.independent.co.uk/news/world/europe/italy-refugee-migrants-boat -stranded-docks-matteo-salvini-mediterranean-sea-a8392946.html.

3 On the role of antiquity in the formation of the Italian nation, see Antonio De Francesco, The Antiquity of the Italian Nation: The Cultural Origins of a Political Myth in Modern Italy, 17961953 (Oxford: Oxford University Press, 2013). For the use of Roman antiquity as models for Italian unification, see Henrik Mouritsen, Italian Unification: A Study in Ancient and Modern Historiography (London: Institute of Classical Studies, 1998).

4 The subject of Italian romanità - symbolic and political evocations of ancient Rome - has received much scholarly interest in recent decades. For romanità in general, see Andrea Giardina and André Vauchez, Il Mito di Roma: Da Carlo Magno a Mussolini (Rome and Bari: Laterza, 200o); and Luciano Canfora, Ideologie del Classicismo (Milan: Einaudi, 1980). For the city of Rome specifically, see Peter Bondanella, The Eternal City: Roman Images in the Modern World (Chapel Hill and London: The University of North Carolina Press, 1987).

The continuity between pre-Fascist and Fascist romanità is rarely emphasised. For an exception, on romanità, mare nostrum, and Italian nationalism in the nineteenth and twentieth centuries, see Marielle Cagnetta, 'Mare Nostrum: Roma e nazionalismo italiano fra Otto e Novecento,' Mededelingen van het Nederlands Historisch Instituut te Rome 53 (1994): 36-43; 
particular on how the ancient Roman concept of mare nostrum was deployed to anchor Italian imperialism in Africa ideologically, both during the liberal and Fascist periods, and the legacy of this project with regard to Italy's political relationship with the Mediterranean today. I frame this discussion with reference to the so-called 'refugee crisis' in the Mediterranean, to consider how Italy's mare nostrum has been reconfigured in the twenty-first century. ${ }^{5}$ This is closely linked to the ways in which the Mediterranean of ancient Roman history and mythology has been articulated into neo-fascist and alt-right discourses on Mediterranean migration. I begin, therefore, by outlining the establishment of the Italian navy's military-humanitarian operation Mare Nostrum, before sketching out the development of this geopolitical concept in Roman antiquity. I move on to consider how mare nostrum resurged in the Italian imagination in the nineteenth and twentieth centuries within the context of Italy's imperial project in Africa, especially Libya and Ethiopia, focusing in particular on the writings of Enrico Corradini, founder of the Associazione Nazionalista Italiana [ANI; Italian Nationalist Association], and later a Fascist. Next, I look at the mare nostrum of the ventennio fascista and its role within Mussolini's Roman Empire. During the period of Italian imperialism in Africa, both liberal and Fascist, I argue that mare nostrum was articulated into a discourse which elided the geographical distance between Africa and Italy, as well as the temporal distance between ancient Roman and modern Italian imperialism. After this, I move forwards chronologically to argue that mare nostrum receded from the national imagination of Italy in the postwar period, concurrent to the

Andrea Perrone, 'Mare nostrum e "Geopolitica". Il mito imperiale dei geografi italiani,' $D i$ acroni 35, no. 1 (2016): 1-20, https://doi.org/10.400o/diacronie.3936; Stefano Trinchese, ed., Mare Nostrum: Percezione ottomana e mito mediterraneo in Italia all'alba del '9oo (Milan: Gerini Studio, 2005). More recently, there has been a wealth of scholarship on Fascist Italian romanità in Anglo-American scholarship. Influential among these have been Romke Visser, 'Fascist Doctrine and the Cult of Romanità,' Journal of Contemporary History 27 (1992): 5-22; Luisa Quartermaine, 'Slouching towards Rome: Mussolini's Imperial Vision,' in Urban Society in Roman Italy, ed. T.J. Cornell and Kathryn Lomas (London: Routledge, 1995), 203-215; Maria Wyke, 'Sawdust Caesar: Mussolini, Julius Caesar, and the Drama of Dictatorship,' in The Uses and Abuses of Antiquity, ed. Maria Wyke and Michael Biddiss (Bern: Peter Lang, 1999), 167186. Recent important contributions from Jan Nelis, Hans Lamers, and Bettina Reitz-Joosse have turned to the written imprint of Fascist romanità, including its revival of the use of Latin. See also Helen Roche and Kyriakos N. Demetriou, ed., Brill's Companion to the Classics, Fascist Italy and Nazi Germany (Leiden: Brill, 2017).

5 See Javier Alcalde, 'Why the Refugee Crisis is not a Refugee Crisis,' Peace in Progress 29 (2016), accessed September 6, 2019, http://www.icip-perlapau.cat/numero29/articles_centrals/ article_central_2/. 
distance between the Italian peninsular and the African littoral widening in the Italian popular imagination, before re-emerging in the era of the European Union as part of the project of European unification. Finally, I turn to the ways in which the conception of mare nostrum is being reshaped in the Italian imagination in connection with the refugee crisis, signifying the return of Italian sovereignty to the Mediterranean. Linked to this, I will briefly examine how the Mediterranean migration of Aeneas is configured both by pro-migration politics and far-right xenophobic rhetoric. I thus argue that the Mediterranean of ancient Rome has played a prominent role in the articulation of twentiethcentury Italian Fascism as a key rhetorical legitimization of imperialism in Africa. It continues to do so within contemporary Italian Fascist and far-right ideologies, albeit that now the Mediterranean represents a site of anxiety, and its liquidity and flux a threat to constructions of European identity.

Indeed, since antiquity, the Mediterranean has been a basin of crosscultural interaction, a site for the negotiation of identities. It was across these waters that the Roman literary imagination looked across at Carthage, seeing in its Punic enemy the polar opposite of itself as well as its mirror image. ${ }^{6}$ The ambivalence of the Mediterranean as a barrier between hostile powers and the vector of contact which gave rise to these powers lies at the heart of the sea's polymorphous, ideologically fluid quality. This, after all, is the landscape of transformation, of Homer's Odyssey and Ovid's Metamorphoses, of Proteus and the Phoenix. ${ }^{7}$ Thus, although the Fascism of the ventennio used the Mediterranean as a means to construct an Italian identity predicated on imperialism, it gave rise to some of the ambivalences that contemporary far-right movements in Italy seek to respond to. This article, by historicising evocations of mare nostrum, therefore argues that a closer examination of Italy's Mediterranean histories enables us to better understand Italian Fascisms past and present, and their relationship to the sea and the lands beyond.

6 Elena Giusti, Carthage in Virgil's Aeneid: Staging the Enemy under Augustus (Cambridge: Cambridge University Press, 2018).

7 Alessando Di Maio, 'The Mediterranean or where Africa does (not) meet Italy: Andre Segre's A Sud di Lampedusa (2006), in Cinemas of Italian Migration: European and Transatlantic Narratives, ed. Sabine Schrader and Daniel Winkler (Newcastle upon Tyne: Cambridge Scholars, 2013), 41-52. Especially poignant in reference to Mediterranean migrations is the myth of the Phoenix. Illegal Mediterranean crossings are termed 'burnings' ('harag' in Arabic), in the sense of burning a traffic light, burning papers, fingertips to avoid identification etc., constituting an incineration of a territorialized identity and rebirth from the ashes. See also Alessandro Triulzi, "Like a Plate of Spaghetti": Migrant Narratives from the Libya-Lampedusa Route,' in Long Journeys: African Migrants on the Road, ed. Alessando Triulzi and Robert McKenzie (Leiden: Brill, 2013), 213-232. 
In October 2013, the world watched on in stunned horror as news broke that two refugee boats off the coast of the Italian island of Lampedusa had shipwrecked, claiming more than six hundred lives. In response, Italy launched its military-humanitarian operation Mare Nostrum in the Mediterranean. ${ }^{8}$ By publicly evoking the memory of Rome's imperial hegemony over the Mediterranean in the name of this operation, Italy was reviving vocabulary drawn from Roman antiquity which, in the nineteenth and twentieth centuries, had been excavated to legitimise Italian claims to sovereignty over the sea and the lands of the opposite shore. The name of the operation therefore represented one of the most recent chapters of the afterlife of this ancient claim to the Mediterranean, which had re-emerged time and again for over two millennia.

In antiquity, Roman hegemony in the Mediterranean depended on the defeat of Carthage. According to the first century CE historian Polybius, Rome's victory in the Second Punic War, fought between 218 and 201 BCE against Hannibal, gave unity to the region. He writes, 'up to this time it had been as if history was that of the scattered deeds of the world .... But from this time, it was as if history becomes one of a single body [ $\sigma \omega \mu \alpha \tau o \varepsilon 1 \delta \hat{\eta} \sigma 0 \mu \beta \alpha i v \varepsilon 1]$, the affairs of Italians and Libyans are intertwined with those of Asia and the Greeks and everything is brought to a single end. ${ }^{9}$ Polybius' history, then, is at least in part about how the Mediterranean became united as the mare nostrum of the Romans.

The unity of the Mediterranean under Roman hegemony began to be challenged in later antiquity. With the split between the Eastern and Western Roman Empires, and the fall of the latter, the Mediterranean could no longer be considered a Roman lake. As the ancient historian Geoffrey Rickman points out, after the fall of the Roman Empire, no single power would again be able to refer to the Mediterranean as 'our sea', mare nostrum. ${ }^{10}$ With the advent and expansion of Islam, the third of the Mediterranean's religions of the book, the sea began to represent a frontier between the Christian and Islamic worlds. With the Ottoman capture of Constantinople, the idea of a Mediterranean split in two, one part Christian, European, and civilized, the other Muslim,

8 Pierluigi Musarò, 'Mare Nostrum: The visual Politics of a Military-Humanitarian Operation in the Mediterranean Sea,' Media, Culture \& Society 39, no.1 (2017): 11-28, https://doi .org/10.1177/0163443716672296.

10 Geoffrey Rickman, 'The creation of Mare Nostrum: $300 \mathrm{BC}-500 \mathrm{AD}$ ', in The Mediterranean in History, ed. David Abulafia (London: Thames and Hudson, 2003), 127-149. 
Oriental, and barbaric, became entrenched in the European imagination. ${ }^{11}$ This discourse of a maritime iron curtain between Christian Europe and Muslim Asia and Africa is, of course, an over-simplification; even at the most tense moments of conflict between these empires of faith, the Mediterranean continued to act as a conduit and network of communication. Nevertheless, it cannot be denied that the Mediterranean region was no longer united under a single hegemonic power, and that Rome's mare nostrum would now lie dormant for the next few centuries. ${ }^{12}$ Moreover the notion of the Mediterranean as a boundary between Christian Europe and the Muslim Other would have clear ramifications for modern xenophobic rhetoric surrounding Mediterranean migrations.

\section{Mare Nostrum and the Unification of Italy}

The myth of mare nostrum underwent significant changes in the modern era. Both before and after Italian unification, Italy was seen as neither Africa nor Europe, its physical position in the middle of the sea no doubt contributing to its perceived liminality. Indeed, Italy's heterogeneity and uneven development between north and south gave rise to a Torinese saying that Garibaldi did not unite Italy, he divided Africa. ${ }^{13}$ Northern Italy's colonial attitudes towards the South of the new state served as a discursive and practical laboratory for overseas colonialism, through which the advocates for imperialism hoped to, having made Italy, 'make Italians.' ${ }^{14}$ The Mediterranean, as mare nostrum, played a

11 Richard W. Clement, 'The Mediterranean: What, Why, and How,' Mediterranean Studies 20, no. 1 (2012): 114-120; Peregrine Horden and Nicholas Purcell, The Corrupting Sea: A Study of Mediterranean History (Oxford: Blackwell, 200o).

12 Horden and Purcell, The Corrupting Sea, 70-75.

13 Ibid., 21.

14 See Nelson Moe, The View from Vesuvius: Italian Culture and the Southern Question (Berkeley: University of California Press, 2002), on the characterisation of Italy as Europe's south, and the emerging Meridionalist discourse and the Southern Question in the decades before and after Italian Unification. See especially page $85^{-18} 3_{\text {for }}$ characterisations of the Southern Italy as the North's internal, barbaric colony. See also, Christopher Duggan, The Force of Destiny: A History of Italy since 1796 (London: Allen Lane, 2007), 259-273; Rhiannon Noel Welch, Vital Subjects: Race and Biopolitics in Italy, 1860-1920 (Liverpool: Liverpool University Press, 2016); Carmen Belmonte, 'Staging Colonialism in the "Other" Italy. Art and Ethnography at Palermo's National Exhibition (1891/92),' Mitteilungen des Kunsthistorischen Institutes in Florenz 59, no. 1 (2017): 86-107. 
pivotal role in the articulation of a discourse of empire which served to unify the fragmented limbs of the young Italian state.

The relationship between Italy, as a modern nation-state, and Africa owes itself not only to the relative geographic proximity between the two, but is given added specificity by the temporal proximity between Italian unification and the Scramble for Africa. ${ }^{15}$ With empire in Africa viewed as a means for Italy to enter into the club of European imperial powers, Tunisia, then a part of the Ottoman Empire, was viewed as a suitable site for Italian colonisation. This was not only as a result of the Tunisia's relative proximity to Italy, but also because of the ancient history of Roman imperialism in the territory of its former nemesis, Carthage, the first part of Africa to be colonised by Rome. However, in 1881, the heavily indebted Ottoman province became a French protectorate, a bitter pill for Italian imperial ambitions to swallow. ${ }^{16}$ It would only be in 1940, during the Second World War, that Italy would right this perceived injustice, when Italian forces seized Tunisia. This, however, would be a short-lived victory: Allied forces retook the region in 1943.

Meanwhile, as early as the late 186os, Italy had embarked on its colonial project in Africa, gaining its first African colonies in Assab, and Massawa in 1869 and 1885 respectively. ${ }^{17}$ With the opening of the Suez Canal in 1871 , these East African coastal outposts were connected to the Mediterranean. As Domenico Tumiati wrote in his 1905 travelogue of Tripolitania, republished in 1911, 'to the south, workers hurry in the Pharaonic sea [Red Sea], to tie Italian Eritrea to the Mediterranean, Tripolitania to Ethiopia'18 Thus, although Italy had its eyes on a Mediterranean empire in emulation of Rome's, the Suez Canal made East Africa a temporarily acceptable substitute.

From its East African possessions, Italy attempted to encroach into Ethiopian territory, leading, in 1887 , to a disastrous defeat at the hands of Ras Alula at Dogali. The defeat was commemorated in a series of essays by the nationalist publicist Alfredo Oriani, collected in a volume entitled Fino a Dogali ['until Dogali']. Although he died in 1909, Oriani would later be claimed by the ideologues of Fascism as a proto-Fascist, to the extent that Mussolini is even

\footnotetext{
15 Welch, Vital Subjects, 10.

16 For Fascist-era historiography's bemoaning of the French control of Tunisia, see Istituto Studi Romani, Africa Romana e Tunisia Italiana: Mare Nostrum III (Rome: Istituto di Studi Romani, 1941).

17 Raymond Jonas, The Battle of Adwa: African Victory in the Age of Empire (Cambridge, MA: The Belknap Press of Harvard University Press, 2011), 35-40.

18 Domenico Tumiati, Nell'Africa Romana: Tripolitania (Milan: Treves, 1911), 291.
} 
credited with editing Oriani's collected works. ${ }^{19}$ His writings, then, offer important clues as to how Italian Fascism perceived its own origins. In this volume, first published in 1889 but republished in 1912, the year following Italy's invasion of Tripolitania, Italy's claims to an African empire were centred on the Mediterranean. The new nation's embarkation on its imperial mission was heralded by Oriani as Rome's re-entry into history, 'sail[ing] one more time on its sea, [as the] bringer of a new civilisation'. ${ }^{20}$ However, at the time of Oriani's writing, Italy would still have to wait more than two decades before returning to the African shores of the Mediterranean long ago colonised by Rome.

\section{Mare Nostrum in the Writings of Enrico Corradini}

A later prominent voice in the project of national unification through imperialism in Africa was that of Enrico Corradini. Corradini, a prominent nationalist and founder of the Italian Nationalist Association, wrote extensively on empire at the time of the Italian invasion of Tripolitania, 1911-1912. ${ }^{21}$ In four volumes of essays published around this time - Il volere d'Italia [Italy's Desire] (1911), L'ora di Tripoli [Tripoli's Moment] (1911), La Conquista di Tripoli (1912), and Sopra le vie del nuovo impero [Over the Roads of the New Empire] (1912) Corradini poses imperialism in Africa as the answer to Italy's domestic problems, and as redemption for the defeats of Dogali (1887) and Adowa (1896), two embarrassing colonial catastrophes inflicted on Italy by Ethiopian armies. Corradini's writings on these topics are significant for a number of reasons. As a pre-Fascist nationalist, and later a prominent Fascist, Corradini is often seen as an intellectual progenitor of Mussolini's movement. ${ }^{22}$ Thus, what Corradini

\footnotetext{
19 Alfredo Oriani, La Rivolta Ideale: Opera Omnia di Alfredo Oriani, a cura di Benito Mussolini (Bologna: Licinio Cappelli, 1930), iii-v.

20 Alfredo Oriani, Fino a Dogali (Bologna: Augusto Gherardi, 1912), 311.

21 See Roberta Viola, 'L'Italia non va, ritorna": Intervento in Libia e opinione nazionalista,' in Mare Nostrum: Percezione ottomana e mito mediterraneo in Italia all'alba del 'goo, ed. Stefano Trinchese (Milan: Gerini Studio, 2005), 97-147, for the broader nationalist discourse on the Italian invasion of Libya.

22 See, for example, Joshua Arthurs, Excavating Modernity: The Roman Past in Fascist Italy (Ithaca and London: Cornell University Press, 2012); Jan Nelis, From Ancient to Modern: The myth of Romanità during the Ventennio Fascista: The Written imprint of Mussolini's Cult of the 'Third Rome' (Brussels: Belgisch Historisch Instituut te Rome, 2011), 31; Emilio Gentile, The Sacralization of Politics in Fascist Italy (Cambridge, MA.: Harvard University Press, 1996), 14.
} 
had to say about the Mediterranean of ancient Rome would have a clear influence on later Fascist discourses of the mare nostrum of imperial Italy.

In an essay in his 1911 collection Il volere d'Italia, entitled 'Lettere dall'Africa Romana', Corradini writes that his first impression of Roman Africa occurred in Naples. ${ }^{23}$ It is no accident that Corradini writes that his initial sense of Roman Africa was in Campania. In another volume of essays from later in the same year as Il volere d'Italia, published once war in Libya had broken out, Corradini states that 'the Southern Question is above all an African Question'. He writes, 'I want to say that the South is like that above all because it neighbours Africa. The primary cause for all the differences between North and South is the difference between Europe and Africa: Northern Italy is linked with the centre of Europe, Southern Italy is aligned towards the African desolation'.24 Thus, Corradini argues in this essay, entitled 'the occupation of Tripolitania is useful for everyone', that if Italy invaded and Europeanized North Africa, it would create 'favourable conditions' for the south of Italy which, at that moment, due to its geography, was 'more African than European, and must be Europeanized'. No class would benefit more from this, Corradini states, than the proletariat. ${ }^{25}$ Here, therefore, the proximity between Africa and Italy is both a problem, contributing to Italy's uneven development, at the same time as being a legitimisation for imperialism on the other side of the Mediterranean; somewhat perversely, invading Libya would serve northern Italy's civilising mission in the south of the country. In short, Italy could become more Italian by compressing the distance between Italy and Africa across the Mediterranean.

It is significant that Africa, in this essay in Il volere d'Italia, is Roman Africa, rather than the modern continent. In the National Archaeological Museum, Corradini meets the art critic and philosopher Angelo Conti, a regular contributor to the review Il Marzocco. Scarcely had Corradini told Conti that he was planning on going to Tunisia, Corradini writes, then,

Conti started talking about the vastness and the magnificence of the Roman Empire and then of the milliarium aureum (golden mile) which was on the Campidoglio and from which all the roads which joined it to the most remote confines departed .... Then he started talking about Africa Romana and gave [Corradini] notes and pointed out books, and the heat of his spirit and his gasping enthusiasm was so great that [Corradini]

\footnotetext{
23 Enrico Corradini, Il volere d'Italia (Naples: Francesco Perrella, 1911).

24 Enrico Corradini, L'ora di Tripoli (Milan: Treves, 1911).

25 Corradini, L'ora di Tripoli, 227-8. Cf. Welch, Vital Subjects, chapters 1 and 2 for the discourse of Northern Italy's educative, civilising mission in the Southern Italy.
} 
seemed to have in front of [him] a veteran of Scipio, on his first day back from the Battle of Zama. ${ }^{26}$

Corradini's idealist roads return in the title of another collection of essays, this one published after the Italian annexation of Libya. The title, Sopra le vie del nuovo impero, Corradini explains, has more of an idealist value than a real value, the roads being more lines of thought than of terrain. ${ }^{27}$ In other authors of this period, we encounter myths of a road running under the Mediterranean, linking Italy to Africa: Giovanni Piazza tells us the legend of 'la via romana sepolta dal mare' [the Roman road buried by the sea], and Paolo Orano speaks of 'great Mediterranean roads', or ways, linking Rome to its Mediterranean colonies. ${ }^{28}$ The Mediterranean then, as a basin of connectivity, links Italy to lands to which, as heir of the Roman Empire, it now stakes a claim. In this respect, Corradini's rhetoric is representative of much of the nationalist discourse on empire in Africa. In Gabriele D'Annunzio's 1907 play Più che l'amore [More than Love], the protagonist, an aspiring colonial adventurer, dreams of Italy being reunited with the sea of which only Italy is worthy. ${ }^{29}$ Similarly, in 'La Canzone d'oltremare' [the overseas song] in Merope, the fourth of his Laudi cycles, written to celebrate the invasion of Libya, D'Annunzio announced the return of Victory, and rejoices to hear the 'cry of the martial eagle in the procella [storm]', and to smell the salty air of 'mare nostrum'. ${ }^{30}$ Such rhetoric would come to have significant influence on the imperial ideology of Fascist romanità. ${ }^{31}$ This is particularly the case for D'Annunzio's imperialist rhetoric, since Martin Winkler

26 Corradini, Il volere d'Italia, 105.

27 Enrico Corradini, Sopra le vie del nuovo impero (Milan: Treves, 1912), ix.

28 Giuseppe Piazza, La Nostra Terra Promessa (Rome: Bernardo Lux Editori, 1911), 116; Paolo Orano, Il Mediterraneo (Naples: Lega Navale, 1911), 20.

29 Gabriele D'Annunzio, Più che l'amore (Milan: Treves, 1907), 46-47. D'Annunzio is particularly important for his influence on early Fascism, and for discussion on the continuity of pre-Fascist and Fascist romanità. Instituting the 'Roman salute' as a nationalist symbol during his irredentist occupation of Rijeka (Fiume), 1919-1920, he was also a vocal proponent of overseas Italian imperialism. See Marielle Cagnetta, 'Idea di Roma, colonialismo e nazionalismo nell'opera di D'Annunzio,' Quaderni del Vittorale 23 (1980): 169-186; Martin M. Winkler, The Roman Salute: Cinema, History, Ideology (Columbus: The Ohio State University Press, 2009), 94-112.

30 Gabriele D’Annunzio, Versi d'amore e di gloria, vol. 2 (Milan: Mondadori, 1984), 647-648.

31 For more mare nostrum of pre-Fascist Italian imperialism in Africa, see for example, Tumiati, Nell'Africa Romana; Adriana M. Baranello, 'Giovanni Pascoli's “La grande proletaria si e' mossa": A Translation and Critical Introduction,' California Italian Studies 2, no. 1 (2011), available at https://escholarship.org/uc/item/6jho7474, accessed September 6, 2019. 
goes so far as to suggest that 'it is no exaggeration to say that the founding father of Fascism was D'Annunzio and that his most observant disciple was Mussolini'. ${ }^{32}$

During the Fascist period of Italian imperialism, the myth of mare nostrum experienced ever increasing prominence. The roots of an Italian empire in Africa laid down during the liberal period were consolidated under Fascism, while the homogenising tendency of imperial romanità was accelerated such that, in 1936, Mussolini was able to proclaim that the Roman Empire had been reborn under the sign of the fasces. ${ }^{33}$ Italian imperialism no longer modelled itself on the Roman Empire; it had become it. A decade earlier, a lecture on 'Roma antica sul mare' [Ancient Rome at Sea] was given by Mussolini at the Università per Stranieri di Perugia. The lecture is striking for unifying the theme of maritime supremacy with romanità in this early statement of Fascist Italian imperial aspirations. ${ }^{34}$ Thus, almost as soon as Fascism came into government in 1922, it reinvigorated efforts to extend Italian control in its Libyan colonies of Tripolitania and Cyrenaica. This meant crushing the resistance to Italian colonial rule represented by the Senussi confederacy. ${ }^{35}$ Rodolfo Graziani, the Fascist military commander in Libya who was later dubbed the 'Butcher of the Fezzan', in his account of this campaign entitled Cirenaica Pacificata [Cyrenaica Pacified], clearly evoking Roman imperialism in its Latin title, names his last chapter 'Senussia delenda' [The Senussi must be destroyed]. He explains this choice as 'it being fitting to paraphrase the words of Cato, to

32 Winkler, The Roman Salute, 112.

33 On the totalitarian homogenisation of history-writing and myth-making, see Claudio Fogu, The Historic Imaginary: Politics of History in Fascist Italy (Toronto: University of Toronto Press, 2003); Stefan Berger, with Christoph Conrad, The Past as History: National Identity and Historical Consciousness in Modern Europe (Basingstoke: Palgrave Macmillan, 2015), 2.

34 Benito Mussolini, Roma Anitica sul Mare (Milan: Mondadori, 1926).

35 See Ali Abdullatif Ahmida, Forgotten Voices: Power and Agency in Colonial and Postcolonial Libya (New York and London: Routledge, 2005), 35-36; The Making of Modern Libya: State Formation, Colonization, and Resistance, 2nd edition (Albany, NY: SUNY Press, 2009) 103140; David Atkinson, 'Encountering Bare Life in Italian Libya and Colonial Amnesia in Agamben,' in Agamben and Colonialism, ed. Marcelo Svirsky and Simone Bignall (Edinburgh: Edinburgh University Press, 2012), 155-177. 
make it our phrase: Senussia delenda. ${ }^{36}$ The equivalence drawn between the African enemy of the Italian Empire with the Punic nemesis of Ancient Rome is a theme which recurs throughout the Fascist cultural discourse on Roman Africa ${ }^{37}$ The epoch-defining Punic Wars are invoked repeatedly to add historical significance to events of Fascist imperialism, and to anchor the modern imperial project in the achievements of Roman imperialism, to pose the former as the continuation and development of the latter. This would serve to transform Libya into the quarta sponda of mare nostrum. ${ }^{38}$

Now that Fascist Italy had tightened its grip on the opposite shore of mare nostrum, imperial expansion was on the agenda. A clear signal of intentions appeared in 1934 on the wall of the Basilica of Maxentius, along the newly constructed Via dell'Impero. Unveiled on 21 April 1934, the year before Italy's invasion of Ethiopia, four colossal maps, designed by Antonio Muñoz, depicted the Roman Empire at various stages of its history, from its earliest mythical foundation under Romulus, to when it had attained its greatest extent under Trajan. ${ }^{39}$ In keeping with cartographic practices inherited from Roman

36 Rodolfo Graziani, Cirenaica Pacificata (Milan: Mondadori, 1932), 301. The words often attributed to Cato the Elder when he urged for the destruction of Carthage in $146 \mathrm{вСЕ,}$ censeo Carthaginem esse delendam, abbreviated to Carthago delenda est [I advise that Carthage must be destroyed, or Carthage must be destroyed], appears to be a modern synthesis of words taken from a number of ancient sources. Nevertheless, the substitution of an ancient African enemy of Roman imperialism for a modern African one of Italian imperialism in Graziani's work is emblematic of Fascism's self-representation as the new Roman Empire. On Cato's phrase, see Charles E. Little, 'The Authenticity and Form of Cato's Saying "Carthago Delenda Est", The Classical Journal 29, no. 6 (1934): 429-435.

37 The association between Italian imperialism in Africa and the Punic Wars is a major theme in Italian imperial romanità. The same year as Graziani's Cirenaica Pacificata also saw the inauguration of the Foro Mussolini, and the installation of the Codex Fori Mussolini which was buried under the complex's monumental obelisk. Amatucci's neo-Latin Codex told the story of Fascism within the vocabulary of the opening of book 21 of Livy's Ab Urbe Condita, drawing parallels between the first decade of the ventennio fascista and the Second Punic War. See Han Lamers and Bettina Reitz-Joosse, The Codex Fori Mussolini: A Latin Text of Italian Fascism (London: Bloomsbury, 2016).

38 See, for example, B. Ducati, Dal primo al secondo impero di Roma, ausilio allo studio della storia per gli alunni dell'ordine elementare (Milano: il Maglio, 1939), 71: 'la quarta sponda del Mare Nostro'.

39 Heather Hyde Minor, 'Mapping Mussolini: Ritual and Cartography in Public Art during the Second Roman Empire,' Imago Mundi 51, no. 1 (1999): 147-162, https://doi .org/10.1080/03085699908592907; see Antonio Muñoz, Roma di Mussolini (Milan: Treves, 1935), 221-222. 


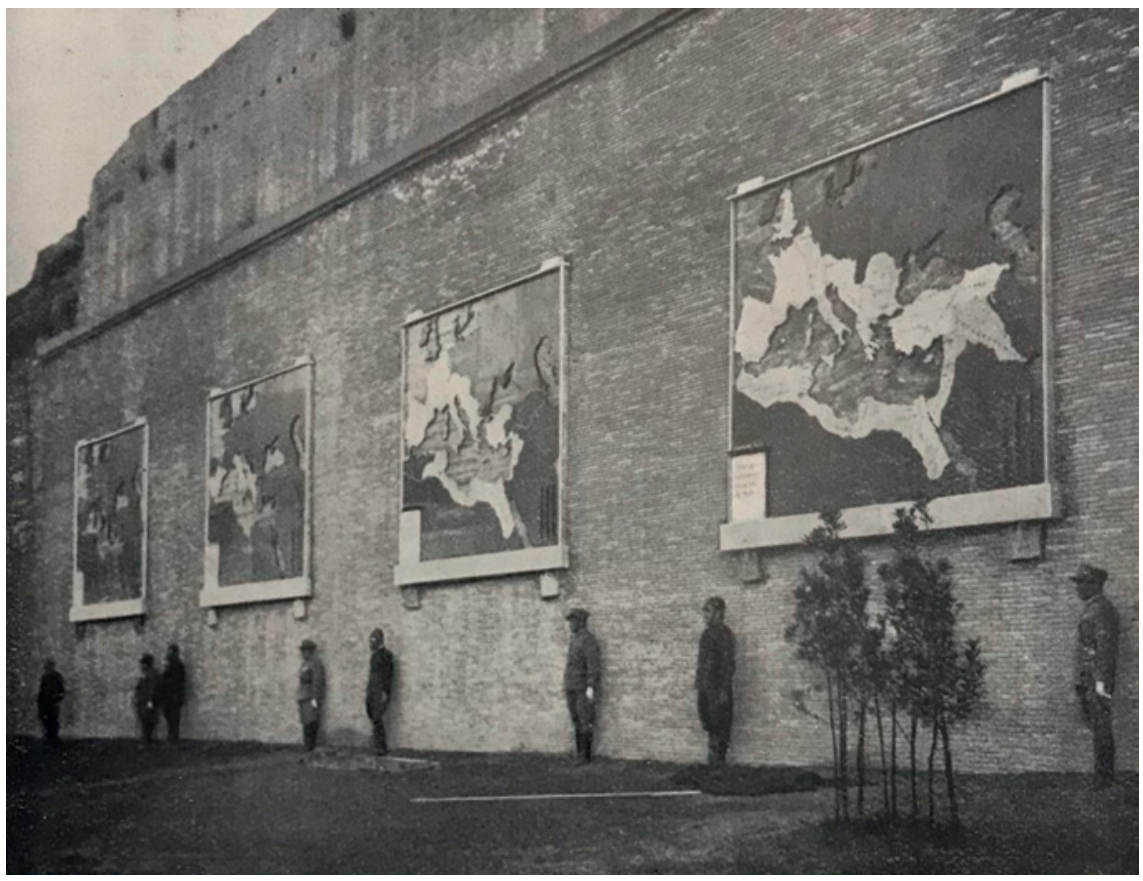

FIGURE 1 Muñoz's Maps.

SOURCE: ANTONIO MUÑOZ, ROMA DI MUSSOLINI (MILAN: TREVES, 1935), 206.

antiquity, the Mediterranean is centred, and at the centre of this was the Italian peninsula and Rome (see figure 1 ).$^{40}$ On the $28^{\text {th }}$ October 1936 , almost six months after Mussolini's proclamation of empire following the completion of Italy's invasion of Ethiopia, a fifth marble map was added to the four which had been put up two years previously. ${ }^{41}$ Now, in addition to representations of the extent of the ancient Roman Empire, here was the New Roman Empire of Mussolini. Similar in design to the other four, the New Roman Empire was represented in white, and the rest of the world in black. It had the same scale as the other four maps, but because more of the world had to be shown, this map was larger than the others. Now that East Africa was included, the role of the Mediterranean in the impero fascista was reconfigured: through the Suez Canal, the Red Sea could now be absorbed into Italian imperial mare nostrum. By placing this fifth map within the continuity of ancient imperialism, Fascist

$40 \quad$ Horden and Purcell, The Corrupting Sea, 12.

41 Benito Mussolini, La Fondazione dell'Impero: Nei discorsi del duce alle grandi adunate del populo italiano con una traduzione latina di Nicola Festa (Naples: Rispoli, 1936). 
Italy's proclamation of empire was anchored by antiquity, and fixed it onto the urban landscape of Rome, as well as in the popular imagination of Italy. ${ }^{42}$

The blank spaces of these maps constitute an important aspect of Italy's colonial discourse. All that is shown in these maps is the empty expanse of the Mediterranean, and the featureless lands surrounding it; those parts under Roman dominion are shown in white, the rest in black. Loredana Polezzi has argued that such representations are characteristic of Italian colonial attitudes towards empire, and in particular Africa. ${ }^{43}$ By highlighting the tension between coasts and interior, the blank spaces of land and sea, Polezzi shows how these maps represent Libya, and Africa in general, by a 'rhetoric of absence' or emptiness. Muñoz's maps partake in this same rhetoric: the only inscriptions of difference on these maps are those denoting Italian sovereignty. Since there is no such distinction in the representation of sea in these maps, it is strongly implied that Italy has claim to sovereignty over the waters of the Mediterranean, given its centrality to these displays of imperial claims. Polezzi argues that such claims to sovereignty over blank space have important consequences for representations of the ongoing humanitarian emergency of Mediterranean migrations. ${ }^{44}$ This is a theme to which I will return at the end of this article.

The blank space of the Mediterranean and Italy's fourth shore served an important function in the construction of imperial, Fascist identities. Italianist Ruth Ben-Ghiat argues that scenes of Mediterranean crossings feature in almost every 'empire film' of the ventennio. These scenes, she suggests, serve to 'initiate travellers into unstable realms of cultural translation and personal transformation:' ${ }^{45}$ The notion of the Mediterranean as a boundary, a place of

42 See Minor, 'Mapping Mussolini,' 153, fig. 6: a photomontage from Italia Imperiale (Milan: La rivista illustrata del Popolo d'Italia, 1937). The poster reads, 'Roma deve apparire meravigliosa a tutte le genti del mondo: vasta, ordinata, potente come fu ai tempi del primo impero d'Augusto' ['Rome must appear magnificent to all the people of the word: vast, organised, powerful as it was at the times of the first empire of Augustus'].

43 Loredana Polezzi, 'Il pieno e il vuoto: Visual Representations of Africa in Italian Accounts of Colonial Experiences,' Italian Studies 67, no. 3 (2012): 336-359, https://doi.org/10.1179/o 075163412Z.ooooooooo23; Loredana Polezzi, 'Description, Appropriation, Transformation: Fascist Rhetoric and Colonial Nature,' Modern Italy 19, no. 3 (2014): 291, https://doi.org/10 .1080/13532944.2014.927355; Loredana Polezzi, 'Looking Across: Images of Libya through Italian eyes,' Lecture, Society for Libyan Studies, British Academy, London, October 9, 2018.

44 Polezzi, 'Looking Across'.

45 Ruth Ben-Ghiat, 'Italian Fascism's Empire Cinema: Kif Tebbi, the Conquest of Libya, and the Assault on the Nomadic,' in Postcolonial Cinema Studies, ed. Sandra Ponzanesi and Marguerite Waller (London and New York: Routledge), 20-31. 
'interactions and interviews', served, in the Fascist, imperial imagination, a positive function. ${ }^{46}$ In films of the Fascist period themed around imperialism in Africa, be it about the ancient Roman Empire, as in Carmine Gallone's 1937 film Scipione l'Africano, or that of twentieth century Italy, such as Mario Camerini's 1928 film of the Italo-Turkish War, Kif Tebbi, Mediterranean crossings are 'all about the male body, trying to break free of temptation and render themselves to the service of Fascist goals.' ${ }^{47}$ Thus, for Italian Fascism in its imperialist period, Mediterranean crossings acted as an ideological motor, propelling Italian society towards totalitarianism, standing in clear contrast to the ways in which Mediterranean crossings are figured in the imagination of contemporary Italian Fascisms.

The theme of mare nostrum continued to be rhetorically powerful in Italian propaganda during the Second World War. For example, a series of pamphlets entitled Mare Nostrum were published by the Istituto di Studi Romani in the early 1940s, dedicated to Italian troops ostensibly fighting so that 'the Mediterranean turns Roman'48 These pamphlets served to situate Italy's war efforts in the Mediterranean within the context of Italy's Mediterranean histories. For example, in one pamphlet on Imoderni carthagi, Italy's British enemies in the Second World War are compared to the Carthaginians, with Fascist Italy playing the role of Rome. The British and Carthaginian empires, according to this pamphlet, built a mercantile empire on maritime power, representing a rapacious utilitarianism, in antithesis to the Roman and Italian idealist spirit of self-sacrifice. ${ }^{49}$ Another pamphlet in this series looks to Roman antiquity in Tunisia to legitimize Italy taking possession of this North African country during the Second World War. The rhetoric of this pamphlet is strikingly similar to that used to glorify the Italian invasion of Libya some thirty years earlier: that of compressing the distance of time separating Roman imperialism in Tunisia and that of Fascist Italy, where Tunisia is configured within its Mediterranean geographical context. For example,

46 Iain Chambers, Mediterranean Crossings: The Politics of an Interrupted Modernity (Durham, NC and London: Duke University Press, 2008), 39.

47 Ben-Ghiat, 'Italian Fascism's Empire Cinema,' 21.

48 Istituto di Studi Romani, I Moderni carthagi: Mare Nostrum II (Rome: Istituto di Studi Romani, 1940). On the propagandistic function of the $I S R$, see Jan Nelis, 'La "fede di Roma" nella modernità totalitaria fascista: Il mito della romanità e l'Istituto di Studi Romani tra Carlo Galassi Paluzzi e Giuseppe Bottai,' Studi Romani 58, no. 1-4 (2010): 359-381; Jan Nelis, 'Back to the Future: Italian Fascist Representations of the Roman Past,' Fascism:Journal of Comparative Fascist Studies 3 (2014): 1-19, https://doi.org/10.1163/22116257-00301001. 
If one can imagine that a country, inseparably linked through two thousand years with the fortune of Rome and Italy, a country which on one hand is an imminent danger for our sea frontier [because of the North African theatre of war], a country which the Italians over almost two thousand years has made to flourish and re-flourish with their intelligence, with their enthusiasm and work, how can one violate with arms and with impunity these Italians? ${ }^{50}$

Thus, in these pamphlets, ancient Rome's mare nostrum is used to stake claims to North African territories, and to cast Fascist Italy's enemies as modern incarnations of ancient Rome's African nemesis. The emphasis on the close relationship between Italy and North Africa, based on Roman history on the other side of the Mediterranean, highlights Italy's self-positioning in relation to Africa.

Later in the war, after the defeat at El-Alamein, and once it had become clear that Italy was fighting a losing battle in North Africa, this relationship towards Africa was cast in a less triumphalist light. In a 1943 booklet in Roma e Africa, published by the Reale Istituto di Studi Romani, the eminent archaeologist Pietro Romanelli assessed the historical relationship between Italy and Africa. He sees the history of Italy as inseparable from that of Africa: 'Rome and Africa cannot ignore each other, they cannot but meet in the sea in which one and the other bathe: from the meeting can come struggle or friendship, but a relationship has from birth been inevitable.51

Thus, even as Fascist Italy's Roman Empire was crumbling around Mussolini's ears, Italy continued to position itself in relation to Africa. Although the Fascist imperial project now seemed doomed to failure, this represented the vicissitudes of history's cycles of epochal struggles between Italy and Africa: from that between Rome and Carthage, or that between the empire and Genseric, the Vandal ruler of North Africa and Sicily, to that of Fascist Italy and the modern Carthaginian British and French Empire. ${ }^{22}$ For Romanelli, in this context, Italian history would always be tightly bound up with the Mediterranean and its opposite African shores.

\footnotetext{
50 ISR, Imoderni carthagi, 20-21.

51 Pietro Romanelli, Roma e l'Africa: Quaderni dell'Imperi: Roma e il Mediterraneo (Spoleto: Reale Istituto di Studi Romani, 1943), 18.

$5^{2}$ Romanelli, Roma e l'Africa, 18. For Genseric see Averil Cameron, 'The Vandal Conquest and Vandal rule (A.D. 429-534), in The Cambridge Ancient History, vol. 14: Late Antiquity: Empire and Successors, A.D. 425-6oo. XIV, ed. Averil Cameron, Bryan Ward-Perkins, Michael Whitby (Cambridge: Cambridge University Press, 2000), 553-559.
} 
However, after the Second World War, and the collapse of first Fascist Italy and then Mussolini's Italian Social Republic, Italy's claims to mare nostrum seemed to have been washed away by the tide of history. Yet towards the end of the last century, buoyed by the optimism of the European project, new discourses of the Mediterranean started to emerge in Italy. An inscription on the Capitoline Hill in Rome celebrates the convening of representatives of the twenty-five member states of the European Union in Rome to sign the abortive constitution of 2004. Written in Latin, it is redolent of ancient solemnity. It announces that

in the famous and majestic hall

named after the Horatii and the Curiatii, the supreme leaders of the nations

joined together in the European Union signed the treaty adopting a constitution,

that with a single mind, a single will, a single purpose

the nations of Europe might merge as the body of a single people. 53

The choice to inscribe this commemoration in Latin alludes to the longstanding idea of Latin as a universal language, ${ }^{54}$ which could now serve as a suitably solemn language to memorialise the coming together of the peoples of Europe. It is striking that the neighbouring inscription, commemorating the Treaty of Rome of 1957, is in Italian rather than in Latin. ${ }^{55}$ The implication of the classicising rhetoric of the 2004 inscription is a resurgent Italian national confidence, such that the state could once again adopt the vocabulary of ancient Rome. Additionally, the emphasis in this inscription on singularity of mind, will, purpose, and people, at the same time as echoing Polybius, evokes the biopolitical drive of Italian imperialism, namely to formulate a unified identity

53 Translation by Tyler Lansford, The Latin Inscriptions of Rome: A Walking Guide (Baltimore: The Johns Hopkins University Press, 2009), 24-25.

54 See Jürgen Leonhardt, Latin: Story of a World Language (Cambridge, MA.: Belknap, 2016); see also Han Lamers and Bettina Reitz-Joosse, 'Lingua Lictoria: The Latin Literature of Italian Fascism,' Classical ReceptionsJournal 8, no. 2 (2016) 216-252, https://doi.org/10.1093/ crj/clvoo1; Han Lamers, Bettina Reitz-Joosse, and Dirk Sacré, 'Neo-Latin Literature - Italy: Fascism (1922-1943),' in Brill's Encyclopaedia of the Neo-Latin World: Micropaedia, ed. Philp Ford, Jan Bloemendal, and Charles Fantazzi (Leiden: Brill, 2014), 1091-1096, for Latin as a universal language under Italian Fascism.

55 My thanks to Frederick Whitling for alerting me to this. 
for the Italian people. In short, this inscription poses the European Union as an heir to the Roman empire.

But where would the frontier of this new European political unity be drawn? How could Europe define itself against what was not Europe? As internal borders appeared to dissolve within this new European body, its external borders became increasingly militarized. ${ }^{56}$ Where, prior to the decolonization of North Africa, the southernmost border of Europe was the edge of the Sahara, now it had officially shifted northwards to the Mediterranean. ${ }^{57}$ The increasingly rigid definition of 'the body of a single people' of Europe necessitated a clear boundary to be drawn between Europe and what was not Europe, and the exclusion of bodies that threatened this constructed identity from Fortress Europe. Where, in the era of liberal and Fascist Italian imperialism, Italy's proximity to Africa and its relative continental liminality appeared as a boon to imperial projects of national formation, now, this was a threat. ${ }^{58} \mathrm{~A}$ new rhetoric of fear around immigration began to emerge. This fear of this African Other was weaponized by Colonel Ghaddafi, the dictator of Italy's ex-colony of Libya. At the same time as the Schengen zone was propelling member states towards greater European unification during the 1990s, Libya's pan-African immigration policy opened the doors of the North African nation to migrants from across the continent. Periodically, Ghaddafi threatened to unleash waves of African migrants, many of whom had originally departed from Somalia and Eritrea, two former Italian colonies, across the Mediterranean to threaten the walls of Fortress Europe. The Libyan port of Zuwara, which had served as the beachhead for Italy's 1911 invasion, now served as a major hub for people-smuggling across the sea. ${ }^{59}$

56 See Triulzi, 'Like a Plate of Spaghetti'; Albahari, Crimes of Peace.

57 Chambers, Mediterranean Crossings, 6. However, as France's garrisoning of the Sahel under the auspices of the $\mathrm{G}_{5}$ 'cross-border task force' show, decolonization remains a slippery process. 'G5 Sahel Joint Force and the Sahel Alliance,' France Diplomatie, updated February 2019, accessed September 6, 2019, https://www.diplomatie.gouv.fr/en/frenchforeign-policy/defence-security/crisis-and-conflicts/g5-sahel-joint-force-and-thesahel-alliance/.

58 See Roberto M. Dainotto, 'The European-ness of Italy: Categories and Norms,' Annali d'Italianistica 24 (2006): 19-39; see also Welch, Vital Subjects, for the myth that Italian racism was new in the 1980s, aside from the Fascist 'parenthesis', as a result of newly rigid categories of Europeanness and non-Europeanness, and the rigidification of Italian national identities in the face of immigration.

59 Albahari, Crimes of Peace, 192. 
It is therefore unsurprising that it was during this period that the Italian neoFascist organisation CasaPound, named after Ezra Pound, was established. ${ }^{60}$ Although numerically small, CasaPound, founded in 2003, represents an extremely militant, terroristic force of the Italian far right, whose members constitute a close-knit, coherent political community ${ }^{61}$ Its symbol, the 'arrowed turtle', represents an ancient, wise animal that carries its home with it. Moreover, it alludes to the Roman military formation of testudo, by which 'the army of Rome showed its greatness in conquering the then known world, showing that the force that emerged from a vertical order and a hierarchical principle is destined to dominate barbarism, even if in smaller numbers. ${ }^{62}$ Despite emphasising the association between its symbol, the turtle, and its capacity for migration, the organisation places anti-immigration politics as a cornerstone of their ideology, which triangulates nation, state, and identity. ${ }^{63}$ Taking its cue from Mussolini's pro-natalist drive announced in 1927, in 2017 CasaPound announced a 'National Birth Income' policy, to offer incentives for Italian mothers to procreate, contributing to the overall aim of getting 'immigrants out,

6o For a problematization of this narrative, see Robert Miles, 'A Rise of Racism and Fascism in Contemporary Europe? Some Sceptical Reflections on its Nature and Extent,'Journal of Ethnic and Migration Studies 20, no. 4 (1994): 547-562, https://doi.org/10.1080/136918 3 X.1994.9976453. For the appeal of CasaPound within the context of the consequences of the 2008 financial crisis, see Pietro Castelli Gattinara, Catterina Froio, and Matteo Albanese, 'The Appeal of Neo-Fascism in Times of Crisis: The Experience of CasaPound Italia,' Fascism: Journal of Comparative Fascist Studies 2 (2013): 234-258, https://doi .org/10.1163/22116257-00202007.

61 Maddalena G. Cammelli, 'Fascism as a Style of Life: Community Life and Violence in a Neofascist Movement in Italy', Focaal 79 (2017): 89-101, https://doi.org/10.3167/fcl.2017 .790108 .

62 CasaPound Italia, 'Il Simbolo,' CasaPound Italia.org, 22 March 2013, accessed September 6, 2019, https://www.casapounditalia.org/il-simbolo/.

63 CasaPound Italia, 'Sul fronte dell'essere: Le proposte di CasaPound sull'immigrazione,' CasaPound Italia.org, 13 September 2013, accessed November 11, 2019, https://www.casapounditalia.org/sul-fronte-dellessere-le-proposte-di/; Cf. Giovani Gentile, Origins and Doctrine of Fascism (New Brunswick and London: Transaction Publishers, 2003) for the doctrine of original Italian Fascism. Comparison between Giovanni Gentile's writings here and CasaPound's ideology show the latter to be authentically fascist. See also Daniele Di Nunzio and Emanuele Toscano, Dentro E Fuori Casapound (Roma: Armando, 2011), 118, and Eugenia Zena, "Fascisti del Terzo Millennio? No, solo Fascisti": The Politics of CasaPound,' E-International Relations Students.info, 5 October 2018, accessed September 6, 2019, https://www.e-ir.info/2018/10/05/fascisti-del-terzo-millennio-no-solo-fascisti-the -politics-of-casapound/. 
Italian babies in'.64 Where Mussolini's Fascism had sought to absorb North Africa into Italy, incorporating Libya into metropolitan Italy in 1939, with the aim of completing national (re)unification, the Italian far right of the twenty-first century was now trying to re-establish the distance between Italy and Africa across the Mediterranean. Although CasaPound alludes to Roman antiquity in its symbols, it wants nothing to do with claims to mare nostrum, even when it glorifies the empire-building of ancient Rome.

\section{Mediterranean Crossings, Ancient and Modern}

Faced with increasing pressure from the anti-immigration right in the aftermath of the 2008 financial crisis, the Italian government was pressured into acting decisively. Thus, in 2008, in exchange for financial and political concessions, as well as some reparations for Italy's colonial atrocities in Libya, Ghaddafi promised oil and agreed with Berlusconi to cooperate with Italy to control migration across the Mediterranean. ${ }^{65}$ As a symbol of this rapprochement between these countries, Italy returned to Libya the stolen Venus of Cyrene, a Roman statue excavated in colonial Libya. ${ }^{66}$ This ancient artefact embodied the long, multi-layered history of the relationship between Italy and Libya, played out across more than two millennia: from imperialisms ancient and modern, where the Mediterranean fulfilled its role as mare nostrum for Italy, to the twenty-first century, when mare nostrum becomes 'mare aliorum' - someone else's sea. ${ }^{67}$

When the Libyan Civil War broke out on the centenary year of Italy's invasion of Tripolitania, Ghaddafi reopened the migration routes across the Mediterranean. ${ }^{68}$ Now that the flow of people had taken on a south to north orientation

64 CasaPound Italia, 'Fuori I Clandestini, Dentro I Bambini Italiani: Casapound Lancia Il Reddito Nazionale Di Natalità, CasaPound Italia.org, 6 March 2017, accessed September 6, 2019, https://www.casapounditalia.org/fuori-i-clandestini-dentro-i-bambini/.

65 Triulzi, 'Like a Plate of Spaghetti,' 214.

66 Mia Fuller, 'Libyan Genocide 2.0: Today's Conflict in Light of a Colonial Past,' Fair Observer, September 5, 2011, https://www.fairobserver.com/region/middle_east_north_africa/ libyan-genocide-2o-todays-conflict-light-colonial-past/; Magnus Treiber, 'Lessons for Life: Two Migratory Portraits from Eritrea,' in Long Journeys: African Migrants on the Road, ed. Alessandro Triulzi and Robert McKenzie (Leiden: Brill, 2013), 187-211.

67 Claudio Fogu, 'From Mare Nostrum to Mare Aliorum: Mediterranean Theory and Mediterraneism in Contemporary Italian Thought,' California Italian Studies 1 (2010): 1-23, available at https://escholarship.org/uc/item/7vp210p4.

68 Treiber, 'Lessons for Life,' $187-188$. 
across the waters mythologized in the Italian imagination as mare nostrum, Italy turned its back on the sea and the continent to which, as heirs of the Roman Empire, they had previously claimed a birth-right. After the tragic shipwrecks off the coast of Lampedusa in October 2013, which brought migrant deaths to the forefront of the European public imagination, Italy could no longer be seen to totally abnegate its responsibilities over its ex-colonies or the waters previously claimed as its own. In the same month as the Lampedusa shipwrecks, Italy instituted Operation Mare Nostrum, a military-humanitarian mission which conceptualized the Mediterranean as a humanitarian 'battlefield. ${ }^{69}$ Thus, the idea of Italy's mare nostrum had made a return in a different guise. The emphasis of this operation was that of policing mare nostrum - fingerprinting arrivals, prosecuting smugglers, and deterring further migration..$^{70}$ Even so, the humanitarian aspect of the Italian naval operation proved to be unpopular, criticized as a state-operated ferry service for migrants. ${ }^{71}$

If Operation Mare Nostrum was a claim to responsibility over what Gabriele D'Annunzio had, in 1901, called the 'Latin sea, ${ }^{72}$ made once again by Italy in the context of policing its waters, it was a claim which fell flat. The unpopularity of the operation suggested that the Italian nation no longer had any taste for extending its influence beyond its borders. Mare Nostrum was discontinued after a year and replaced with an operation launched in collaboration with the European Union's Frontex Border and Coast Guard Agency. Tellingly, this 2014 operation, more aggressively securitarian than the previous year's, was named Mos Maiorum. Alongside the names of other Frontex Mediterranean border policing operations, Poseidon and Hermes in 2011, Triton in 2014, the classicising name of this operation is striking. The name refers to the Ancient Roman idea of public and private life being regulated by the ways of the ancestors, encompassing ideas of tradition, customs, and unwritten laws. According to Livy (1.8.7), the belief was that the mos maiorum [ancestral custom] had existed from the beginning of Rome, having been established by Romulus. Mos maiorum protected the authority of the aristocracy, who were seen as the guardians of tradition. ${ }^{73}$ Thus, it represented an exclusive cultural formation,

69 Musarò, 'Mare Nostrum.'

70 Albahari, Crimes of Peace.

71 Ibid.

72 D'Annunzio, Versi d'amore, vol. 2 (1984), 654.

73 See Wilhelm Kierdorf, 'Mos Maiorum,' in Brill's New Pauly: Encyclopaedia of the Ancient World (Leiden: Brill, 2006), 9, 216-218; Nathan Rosenstein, 'Mos Maiorum,' The Oxford Encyclopaedia of Ancient Greece and Rome (Oxford: Oxford University Press, 2010), 1-2; Olga Tellegen-Couperus, A Short History of Roman Law (London and New York: Routledge, 1990), 17 . 
handed from one generation to the next, defining what it was to be Roman. To name a securitarian operation after mos maiorum sent a clear message - the aim of the Italian navy was no longer to assert its responsibility over its sea, but to protect and regulate social life through adherence to tradition. This meant keeping outsiders outside. Thus, mos maiorum signalled Italy's shutting itself off from mare nostrum.

Here, we are brought back to Leoluca Orlando's comments about Palermo's historic place in the Mediterranean as a place of refuge. Orlando's words show how the antiquity of the Mediterranean can be deployed to promote a politics of openness and acceptance. By this token, against the backdrop of the refugee crisis, a wealth of commentary has evoked Aeneas, the Trojan prince immortalized in Virgil's Aeneid, who fled from Troy as it burned, to Italy. ${ }^{74}$ Indeed, Operation Mare Nostrum was instituted as the merging of two pre-exiting rescue operations: Operation Hermes and Operation Aeneas. ${ }^{75}$ However, classicist Elena Giusti writes that evocations of Aeneas in support of refugees and migrants to Italy is not enough, since, 'we need to open our eyes seriously to the different and intersectional identities of the contemporary readers of these texts, especially women, LGBTQ+, and Italians of colour.' ${ }^{76}$ In other words, there is no single correct reading of Aeneas. Aeneas, while the mythical refugee par excellence, was also an emblem of twentieth century Italian imperialism. Just as Italy staged a 'return' to the formerly Roman territories of Libya, so, by that act, did D'Annunzio celebrate the return of the 'native spirit [genio indigete] of the seed / of Aeneas [returning] to us with a divine sign / of the splendour of the far-away sands [of Libya]. ${ }^{77}$ This same narrative of return to North Africa propelled the likes of Corradini and Domenico Tumiati to visit the site

74 For example, Oliver Kemeid's 2009 play L'Éneide, staged in Milan in 2017. See further examples: Peter Knox, 'In Today's Anti-Immigrant Rhetoric, Echoes of Virgil's "Aeneid", The Conversation, March 21, 2017, https://theconversation.com/in-todays-anti-immigrantrhetoric-echoes-of-virgils-aeneid-74738; Richard Miles, 'What the Romans Can Teach Us about Refugees,' The Guardian, June 24, 2011, https://www.theguardian.com/commentisfree/2011/jun/24/roman-refugees-battle-adrianople; George Saad, 'Refugees by Fate, Founders by Choice,' Eidolon, April 5, 2018, https://eidolon.pub/refugees-by-fate-founders -by-choice-daf410do838.

75 Florian Trauner, 'Asylum policy: The EU's ‘Crises' and the Looming Policy Regime Failure,' Journal of European Integration 38, no. 3 (2016): 311-325, https://doi.org/10.1080/07036337 .2016 .1140756 .

76 Elena Giusti, 'Romans go... where?', Eidolon, October 11, 2018, https://eidolon.pub/ romans-go-where-7641ef2a43b2.

77 From 'Le conzone del sangue,' D'Annunzio, Versi d'amore, vol. 2 (1984), 659. 
of Carthage, shortly before and during the Italian invasion of Libya, in order to retrace the footsteps of Dido and Aeneas, and to stage their own returns. ${ }^{78}$

In the twenty-first century, the much-contested figure of Aeneas continues to be articulated into nationalist discourse. However, unlike twentieth-century nationalists' use of Aeneas to promote imperialism as a means to consolidate national unification and 'to make history', the contemporary Italian right's evocations of the legendary hero are reactionary and defensive against the perceived threat of immigration. In other words, rather than representing a figure for an expansionist conception of the Italian nation, Aeneas is reconfigured to stand for a contracting, narrowly defined nation, in terms of territory and ethnicity.

Giusti points to an article from 2018 on the alt-right website Giovani a Destra, which argues that 'Aeneas was not a migrant, and above all, was not a Turk'. In this article, Federica Ciampa argues that Turks only settled on the Anatolian Peninsula in 1100 CE, while the Trojan War is generally dated to around 1250 вСE. Thus, Aeneas could not have been a Turk. Additionally, from the mythical point of view, the article argues that Dardanus settled in Anatolia, having migrated from Arcadia in Greece. According to Virgil, however, Dardanus originated from Etruria. Aeneas, then, as a descendent of Dardanus, was Italian, and Italy was already his homeland. The article goes on to state that Aeneas did not flee war, because he only left Troy after the war was over and after fighting valiantly alongside his compatriots. He is a profugus only because of providential fate. The article concludes: 'It seems clear, therefore, that there are no Aeneases among the new migrants: they do not return to their homeland; they do not go to uninhabited and economically prosperous places, but, on the contrary, they head towards an Italy that has other important emergencies to face in this historical period. 79

A 2016 article in Il Primato Nazionale, the periodical of CasaPound, argues for Aeneas' indigenous Italian status along similar lines. This article attacks socalled 'immigrationist theories' and their appropriations of the figure of Aeneas. The article argues that 'It is normal to try to comfort one's theories by citing examples taken from classicism in virtue of the authority that, even

78 Tumiati, Nell'Africa Romana, 269-267; Corradini, Il volere d'Italia, 106-111. Cf. Massimiliano Munzi, L'Epica del Ritorno: Archeologia e politica nella Tripolitania Italiana (Rome: L'Erma di Bretschneider, 2001) for how this 'epic of return' was played out in Italian colonial archaeology in Tripolitania, in recovering the traces of Rome's civilization there.

79 Frederica Ciampa, 'Enea non era un migrante e, soprattutto, non era turco', Giovani a Destra, April 12, 2018, http://giovaniadestra.it/2018/04/18/enea-non-era-un-migrante -e-soprattutto-non-era-turco/. 
today, classical culture exercises'. It goes on to sardonically contrast Aeneas' piety, respect for women, deference to law and custom with those of migrants to Italy. Like Ciampa, this article stresses the fact that Aeneas is bound by fate and the law of the gods. Here, this article likens this higher will to that of Soros, Draghi, and Obama, recycling far-right anti-Semitic conspiracy theories, here framed by references to Roman antiquity. In case we were in any doubt as to the articles' sarcasm, it ends very clearly: 'No, the refugees are not like Aeneas, they have not come to re-establish civilization; if anything, they have come to forget theirs because someone, like the snakes of the head of Medusa, is petrifying the world. ${ }^{80}$ These two examples of Italian alt right and far right claims to Aeneas demonstrate the flexibility of this mythical figure to contemporary Italian ideologies. As with these reconfigurations of the figure of Aeneas, Italy's relationship to the Mediterranean is protean. A century after Italy's invasion of Libya, anti-immigration politics seeks to cut the peninsula off from the surrounding sea: Italian Fascisms and nationalisms have shifted from claiming mare nostrum to rejecting it.

\section{Conclusion}

How are we to understand this shifting dynamic? Ida Danewid argues that a historicism which centralizes the legacies of imperialism in the region is central to any politics of migrant solidarity in the Mediterranean. ${ }^{81}$ Similarly, Iain Chambers stresses that the rise of xenophobia in Italy in the past decades is as a result of the failure and unwillingness to confront the unconscious European past 'in which colonialism and empire were (and are) distilled into national configurations of "identity", "culture", "modernity", and "progress"' configurations of which are condensed into myths of the Mediterranean. ${ }^{82}$ As these two approaches to migration politics and xenophobia show, it is through the elision of histories that Italian Fascisms have configured Italy's relationship with the Mediterranean. In the twentieth century, this meant transposing the Roman Empire into the modern Mediterranean and North Africa, whereas

\footnotetext{
80 Michael Mocc, 'Enea non era un "profugo", il suo era un ritorno all'origine,' Il Primato Nazionale, May 21, 2016, https://www.ilprimatonazionale.it/cultura/enea-profugo-origine $-45^{275} /$.

81 Ida Danewid, 'White Innocence in the Black Mediterranean: Hospitality and the Erasure of History,' Third World Quarterly 38, no. 7 (2017), 1674-1689, https://doi.org/10.1080/01436 597.2017.1331123.

82 Chambers, Mediterranean Crossings, 7, 12.
} 
contemporary Italian Fascism and more general xenophobic politics have excised Mussolini's claims to the Mediterranean from the historical imaginary. In both cases, the Mediterranean has figured as a significant presence in the selfnarrated stories of Italian Fascism, past and present: from representing the potential for a New Roman Empire, to embodying a critical threat to Italy's European identity. As Polezzi has argued, visualizations of Italy's African colonies as a blank space for the projection of colonial fantasies have important consequences for contemporary Italian imaginings of the humanitarian emergency in the Mediterranean. ${ }^{83}$ When Libya, from which many migrants begin their Mediterranean crossing, is characterized by its emptiness, it becomes defined by the people moving through the region, unchanging in its constant flux. ${ }^{84}$ The appropriation of Libya and mare nostrum as blank spaces in the Italian imagination now serves the reverse purpose to that of the early twentieth century: the Mediterranean and the lands beyond are no longer a canvas for the projection of colonial dreams, but of postcolonial nightmares. This article does not suggest that a reminder of Mussolini's mare nostrum could dispel the racist violence of CasaPound; rather, it hopes that the historicization of these aspects of Fascist ideology might contribute to the articulation of a more compelling discourse of migrant solidarity.

83 Polezzi, 'Looking across.'

84 Polezzi demonstrates this rhetoric in the photos of Luca Sola, Fabio Bucciarelli, and Giulio Piscitelli. 